\title{
No habitat correlation of zooxanthellae in the coral genus Madracis on a Curaçao reef
}

\author{
O. E. Diekmann ${ }^{1,3, *}$, R. P. M. Bak ${ }^{1,2}$, L. Tonk ${ }^{3}$, W. T. Stam ${ }^{3}$, J. L. Olsen ${ }^{3}$ \\ ${ }^{1}$ Institute of Biodiversity and Ecosystem Dynamics, University of Amsterdam, PO Box 94766, 1090 GT, Amsterdam, \\ The Netherlands \\ ${ }^{2}$ Netherlands Institute for Sea Research (NIOZ), PO Box 59, 1790 AB, Den Burg, Texel, The Netherlands \\ ${ }^{3}$ Department of Marine Biology, Centre for Ecological and Evolutionary Studies, University of Groningen, \\ PO Box 14, 9750 AA, Haren, The Netherlands
}

\begin{abstract}
Symbiotic dinoflagellates belonging to the genus Symbiodinium (zooxanthellae) play an important role in ecological specialization and physiological adaptation in corals. We examined the diversity and depth distribution of zooxanthellae in 5 morphospecies of Madracis at the Buoy I studyreef on Curaçao, Netherlands Antilles. Following earlier studies, we examined length and sequence variation in the D1 and D2 domains of the nuclear rDNA, large subunit (LSU) of Madracis-associated zooxanthellae. Both RFLP and sequence comparisons showed that all 5 Madracis morphospecies host a single type of Symbiodinium belonging to phylogenetic Group B sensu Rowan. No correlation was found between zooxanthellae and habitat depth. The presence of the single, Type-B zooxanthellae in all Madracis morphospecies at Buoy I (and from 3 other biogeographic locations in the Caribbean) suggests that 'generalist' zooxanthellae-coral associations are equally successful over a range of habitats and that adaptations to different light and nutrient regimes are not necessarily dependent on the mix of zooxanthellae types or zonation with depth, as has been shown in the well-studied Montastraea annularis complex and Acropora cervicornis. A review of the current literature on zooxanthellae diversity in scleractinians (including biogeographic sampling for some species) shows that most species appear to harbor only 1 zooxanthellae type and that the 3 types of Symbiodinium (A, B, C sensu Rowan) are found at all depths and are thus potentially always available for acquisition.
\end{abstract}

KEY WORDS: Corals $\cdot$ Zooxanthellae $\cdot$ Madracis $\cdot$ Symbiodinium $\cdot$ rDNA $\cdot$ Symbiosis $\cdot$ Brooder Bleaching Resale or republication not permitted without written consent of the publisher

\section{INTRODUCTION}

Zooxanthellae are recognized as unicellular dinoflagellate algae, mainly belonging to the genus Symbiodinium Freudenthal (1962) that live in symbiosis with a variety of different hosts, e.g. foraminifera, jellyfish, anemones, zoanthids, gorgonians, sponges, bivalves and corals (Langer \& Lipps 1994, McNally et al. 1994, Ohno et al. 1995, Rowan \& Knowlton 1995). Symbiodinium was originally thought to be a monotypic genus, but biochemical, physiological, morphological

*Corresponding author. E-mail: o.e.diekmann@biol.rug.nl Address for correspondence: University of Groningen and behavioral studies quickly revealed that Symbiodinium is highly diverse (Blank \& Trench 1985, Blank et al. 1988, Trench 1987) and contains many members (reviewed in Rowan 1998). Molecular genetic studies over the past decade have revealed distinct strains or types of S. microadriaticum (Rowan 1991, 1998, Rowan \& Powers 1991). Using restriction fragment length polymorphism (RFLP) analysis of the small subunit (SSU) ribosomal DNA (rDNA) gene from several cultivated and freshly isolated zooxanthellae from a wide variety of hosts, Rowan \& Powers (1991) identified 3 major phylogenetic groups within Symbiodinium, designated as Type A, B and C. Several subsequent surveys of Symbiodinium diversity in $>50$ coral species 
from the Pacific and Caribbean have revealed the same 3 types (Baker \& Rowan 1997), albeit with some minor differences in Type C (Baker et al. 1997).

It was originally assumed that zooxanthellae were species-specific (Schoenberg \& Trench 1976, Trench 1992), i.e. that the dinoflagellate and coral host had coevolved over evolutionary time. The alternative hypothesis was that symbiont associations were driven by ecological factors alone (Kinzie \& Chee 1979) and thus not co-evolved. When the necessary molecular data to test these hypotheses became available (Rowan \& Powers 1991, 1992, McNally et al. 1994), it became clear that co-evolution had not played a strong role and that ecological rather than historical-evolutionary factors accounted for host-symbiont associations. Following up on this idea, Rowan \& Knowlton (1995) examined zooxanthellae diversity in the polymorphic coral species complex Montastraea annularis in Caribbean Panama. The 3 types (A, B and C) of Symbiodinium were detected, and, most significantly, there was a strong habitat correlation between zooxanthellae type and the depth from which the coral was collected. These results led the authors to hypothesize light adaptation. In a more refined study of zooxanthellae distribution within $1 \mathrm{~cm}^{2}$ areas of individual colonies of $M$. annularis and M. faveolata, Rowan et al. (1997) found similar differences between shaded sides and tops of colonies. Similar zooxanthellae zonation patterns were also found in Acropora cervicornis (Baker et al. 1997). In contrast, a survey of M. cavernosa in Bermuda (Billinghurst et al. 1997) revealed only Type B regardless of depth. It is clear that the types of Symbiodinium and their distribution are highly variable: within and between species; within and between local habitats; and probably, within the local landscape.

Here, we compare zooxanthellae diversity in 5 morphospecies of Madracis Milne Edwards \& Haime (1849) (Scleractinia, Astrocoeniina, Pocilloporidae) at the Buoy I study site on Curaçao, Netherlands Antilles. These included $M$. mirabilis (Duchassaing \& Melotti), M. decactis (Lyman), M. formosa (Wells 1973), M. pharensis (Heller) and M. senaria (Wells 1973). These taxa are typically found in sympatric assemblages on single reefs and range in depth from ca 2 to $>70 \mathrm{~m}$ (Wells 1973). $M$. mirabilis and $M$. formosa are restricted to the shallow 2 to $25 \mathrm{~m}$ ) and deep (>30 m) habitat respectively, whereas $M$. decactis occurs from 5 to $40 \mathrm{~m}$. M. pharensis and $M$. senaria are found across all depths (5 to $>60 \mathrm{~m}$ ) (M. J. A. Vermeij \& R. P. M. Bak unpubl.).

Following earlier studies (Baker \& Rowan 1997, Baker et al. 1997) we compared DNA sequences from the D1 and D2 domains (ca $650 \mathrm{bp}$ ) of the nuclear rDNA large subunit (nucleotide position
36-735 in the gene, Lenaers et al. 1998). We addressed 2 questions: (1) Do different morphospecies of Madracis harbor 1 or more types of zooxanthellae? (2) Is there a correlation between the zooxanthellae type and the depth from which the host coral was collected? Finally, we review the current literature on what is known about zooxanthellae distribution in scleractinians and discuss the implications of flexible and changing, short-term symbiotic associations.

\section{MATERIALS AND METHODS}

Study area and sampling. The island of Curaçao is situated in the southern Caribbean $\left(12^{\circ} \mathrm{N}, 69^{\circ} \mathrm{W}\right)$ about $80 \mathrm{~km}$ off the coast of Venezuela (Fig. 1). Leeward reefs are characterized by a shallow terrace (50 to $100 \mathrm{~m}$ wide), a drop-off at 8 to $12 \mathrm{~m}$, and a steep seaward slope extending to 50-60 m (Bak 1977). Our study site, the Buoy 1 reef, is situated $500 \mathrm{~m}$ west of the Ecological Institute Carmabi and is a long-established site for coral research (e.g. Bak 1977, Bak \& Engel 1979, van Veghel \& Bak 1993, Bak \& Nieuwland 1995, Meesters et al. 2001).

Madracis specimens were collected from depths of 2 to $45 \mathrm{~m}$ (Table 1). Care was taken to ensure that samples of each morphospecies were collected from all depths at which they occurred. Samples consisted of small fragments (ca $50 \mathrm{~cm}^{2}$ ) taken from the living upper surface of individual colonies. These were transported to the laboratory in seawater and transferred to a running seawater-table. Each sample fragment was divided into 2 pieces. One sub-sample was bleached and dried for further skeletal examination, while the second sub-sample was preserved in $70 \% \mathrm{EtOH}$ for DNA extraction. Samples used in the present study of zooxanthellae diversity were also used in a phylogenetic study of the genus Madracis (Diekmann et al.

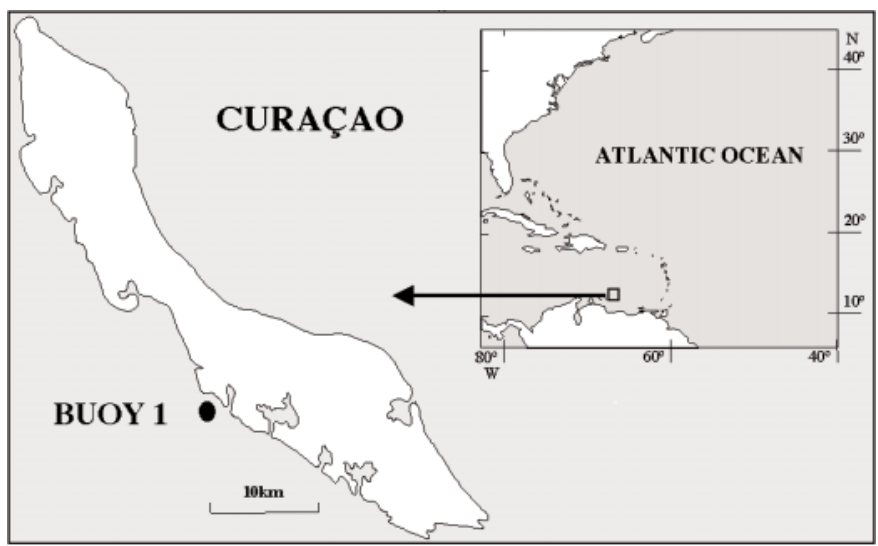

Fig. 1. Curaçao, Netherlands Antilles, and the Buoy 1 study site 
Table 1. List of coral species sampled for zooxanthellae analysis at Buoy 1, Curaçao, Netherlands Antilles

\begin{tabular}{|c|c|c|c|c|c|}
\hline Species & $\begin{array}{l}\text { Lane no. } \\
\text { in Fig. } 2\end{array}$ & $\begin{array}{l}\text { Individual code } \\
\text { used in Fig. } 3\end{array}$ & $\begin{array}{l}\text { Number } \\
\text { of clones } \\
\text { sequenced }\end{array}$ & GenBank accession no. & $\begin{array}{l}\text { Depth } \\
\text { (m) }\end{array}$ \\
\hline Madracis mirabilis & $\begin{array}{l}1 \\
2 \\
3 \\
4\end{array}$ & $\begin{array}{l}\text { M. mirabilis } 1 \\
\text { M. mirabilis } 6 \\
\text { M. mirabilis } 9 \\
\text { M. mirabilis } 55\end{array}$ & $\begin{array}{l}- \\
\mathrm{a}, \mathrm{b}, \mathrm{c}, \mathrm{d} \\
\mathrm{a}, \mathrm{b} \\
\mathrm{a}, \mathrm{b}, \mathrm{c}\end{array}$ & $\begin{array}{l}\text { AF331858, AF331859, AF331860, AF331861 } \\
\text { AF331862, AF331863 } \\
\text { AF331864, AF331865, AF331866 }\end{array}$ & $\begin{array}{r}6.3 \\
24.0 \\
19.0 \\
2.2\end{array}$ \\
\hline Madracis decactis & $\begin{array}{l}5 \\
6 \\
7 \\
8\end{array}$ & $\begin{array}{l}\text { M. decactis } 13 \\
\text { M. decactis } 100 \\
\text { M. decactis } 3 \\
\text { M. decactis } 107\end{array}$ & $\begin{array}{c}\mathrm{a}, \mathrm{b}, \mathrm{c}, \mathrm{d}, \mathrm{e} \\
- \\
\mathrm{a} \\
\mathrm{a}, \mathrm{b}, \mathrm{c}\end{array}$ & $\begin{array}{l}\text { AF331868, AF331869, AF331870, AF331871, AF331872 } \\
\text { AF331867 } \\
\text { AF331873, AF331874, AF331875 }\end{array}$ & $\begin{array}{r}34.7 \\
4.7 \\
29.0\end{array}$ \\
\hline Madracis formosa & $\begin{array}{r}9 \\
10 \\
11 \\
12\end{array}$ & $\begin{array}{l}\text { M. formosa } 11 \\
\text { M. formosa } 12 \\
\text { M. formosa } 15 \\
\text { M. formosa } 25\end{array}$ & $\begin{array}{l}- \\
- \\
a, b \\
a, b\end{array}$ & $\begin{array}{l}\text { AF331876, AF331877 } \\
\text { AF331878, AF331879 }\end{array}$ & $\begin{array}{l}38.8 \\
43.0 \\
38.8 \\
39.6\end{array}$ \\
\hline Madracis senaria & $\begin{array}{l}13 \\
14 \\
15\end{array}$ & $\begin{array}{l}\text { M. senaria } 3 \\
\text { M. senaria } 13 \\
\text { M. senaria } 8\end{array}$ & $\begin{array}{c}\mathrm{a} \\
\mathrm{a}, \mathrm{b}, \mathrm{c} \\
-\end{array}$ & $\begin{array}{l}\text { AF331880 } \\
\text { AF331881, AF331882, AF331883 }\end{array}$ & $\begin{array}{l}10.8 \\
32.3 \\
13.4\end{array}$ \\
\hline Madracis pharensis & $\begin{array}{l}16 \\
17 \\
18 \\
19\end{array}$ & $\begin{array}{l}\text { M. pharensis } 2 \\
\text { M. pharensis } 4 \\
\text { M. pharensis } 11 \\
\text { M. pharensis } 60\end{array}$ & $\begin{array}{l}\mathrm{a} \\
\mathrm{a} \\
- \\
-\end{array}$ & $\begin{array}{l}\text { AF331885 } \\
\text { AF331884 }\end{array}$ & $\begin{array}{r}4.3 \\
7.0 \\
27.0 \\
40.0\end{array}$ \\
\hline Montastraea annularis & is 20 & & 1 & AF331886 & 15.0 \\
\hline $\begin{array}{l}\text { Stephanocoenia } \\
\text { michelinii }\end{array}$ & $\begin{array}{l}21 \\
22\end{array}$ & Uncut LSU fragm & 1 & AF331887 & 13.5 \\
\hline Total & 22 & & 30 & & \\
\hline
\end{tabular}

2001). Samples from 2 other coral species, Montastraea annularis (15 m) and Stephanocoenia michelinii $(13.5 \mathrm{~m})$, were also sampled at Buoy 1 and added in the analysis as reference taxa for Type $\mathrm{C}$ zooxanthellae.

DNA extraction. DNA was extracted using a modified protocol of de Jong et al. (1998). Total DNA was isolated by scraping off the surface layer of the coral sample (3 to $4 \mathrm{~cm}^{2}$ ) and grinding it in a mortar containing $900 \mu \mathrm{l}$ DNA extraction buffer (1.4 M NaCl, $20 \mathrm{mM}$ EDTA, $100 \mathrm{mM}$ Tris-HCl pH 8.0 and 2\% CetylTrimethylAmmoniumBromide) and $0.2 \% \quad \beta$-mercaptoethanol. After grinding the slurry was transferred to a $2 \mathrm{ml}$ Eppendorf tube and incubated at $65^{\circ} \mathrm{C}$ for $1 \mathrm{~h}$. After 1 phenol extraction and 2 CIA (chloroform:isoamylalcohol 24:1 v/v) extractions, the DNA was recovered by overnight precipitation in $100 \%$ ethanol. After centrifugation the pellet was washed 2 times with $80 \%$ EtOH and dried under vacuum. The DNA was dissolved in $100 \mu \mathrm{l} 0.1 \times$ TE (Tris-EDTA, pH 8). Average yield was estimated at ca $1000 \mu \mathrm{g} \mathrm{ml}^{-1}$.

PCR amplification. The D1 and D2 variable region of the large sub-unit ribosomal RNA gene (LSU rDNA) was amplified using universal primers 24D13F1 and 24D23R1 (Baker \& Rowan 1997). A $100 \mu l$ polymerase chain reaction (PCR) consisted of $10 \mu$ l of $10 \times$ Reaction Buffer (Promega, Madison, WI, USA), $10 \mu$ lo $10 \times$ dNTP $(200 \mu \mathrm{M}), 6 \mu \mathrm{l} \mathrm{MgCl}_{2}(25 \mathrm{mM}), 4 \mu \mathrm{l}$ of each primer $(50 \mathrm{mM}), 4 \mu \mathrm{l}$ of template DNA (optimal dilu- tion), and 2.5 units Taq DNA Polymerase (Promega). Test PCRs were performed with undiluted, $10 \times$ and $100 \times$ diluted DNA to find the optimal dilution for each sample. Amplifications were performed in a PerkinElmer 2400 machine with a profile consisting of 1 cycle of $3 \mathrm{~min}, 96^{\circ} \mathrm{C}$, followed by 24 cycles of $1 \mathrm{~min} 94^{\circ} \mathrm{C}$, $2 \min 50^{\circ} \mathrm{C}$ and $2 \min 72^{\circ} \mathrm{C}$, and 1 cycle $1 \min 93^{\circ} \mathrm{C}$, $2 \min 50^{\circ} \mathrm{C}$ and $5 \min 72^{\circ} \mathrm{C}$.

The universal primers amplify zooxanthellae as well as coral DNA but can be differentiated because the D1 and D2 variable regions vary significantly in size between different phyla of organisms (Hillis \& Dixon 1991). The coral fragment was ca 800 bp and the zooxanthellae fragment ca 650 bp (Baker \& Rowan 1997). Typically only 2 bands were amplified. Following separation of the fragments on a $1.5 \%$ TAE agarose gel, the zooxanthellae fragment was cut from the gel. The DNA was recovered by centrifuging (Eppendorf centrifuge at full speed for $10 \mathrm{~min}$ ) the gel slice over siliconized glasswool in a PCR tube placed in a $1.5 \mathrm{ml}$ Eppendorf tube (van Oppen et al. 1994).

RFLP analysis. The cleaned LSU fragment was reamplified using the same PCR conditions as above. The concentration was measured by loading $2 \mu$ l of the product on a $1.5 \%$ agarose gel along with a dilution series of DNA standards (25 to $200 \mathrm{ng}$ ). The yield was quantified using Image-Quant (ver. 4.2) software from Molecular Dynamics (M.B.T. Benelux, Maarssen, The 
Netherlands). The amplification product was digested with the restriction enzymes CfoI and TaqI. These restriction enzymes (RE) are able to distinguish between the 3 zooxanthellae types (Baker et al. 1997). Digestions were performed using $100 \mathrm{ng}$ of PCR product, $1 \mu \mathrm{RE}, 2 \mu \mathrm{l} 10 \times$ reaction buffer in a total volume of $20 \mu \mathrm{l}$ at the appropriate temperature for the specific RE overnight. The digests were separated on $2 \%$ RESponse/1\% RESult (Biozym, Landgraaf, The Netherlands) gels which provide separation of bands in the range of 50 to $8000 \mathrm{bp}$. Based on the RFLP results, samples were selected for sequencing (Table 1).

Cloning. Following reamplification, PCR products were cleaned using Quiaquick PCR Purification Kit (Qiagen GmbH, Hilden, Germany) according to the manufacturer's protocol. The cleaned fragments were ligated into pGEM-T vector, cloned into JM109 competent cells and plated out on $2 \times$ YT medium agar plates containing IPTG, X-gal and Ampicillin for blue/ white screening of the colonies according to the manufacturers protocol (pGEM-T Easy Vector System, Promega). Colony PCR was performed with the same primers used for amplification on positive white colonies to check that the insert size was of the expected length. Plasmid template was used in sequencing reactions.

Sequencing. Cycle sequence reactions were carried out using the ABI Prism BigDye Terminator Cycle Sequencing Ready Reaction Kit (PE Applied Biosystems, Perkin-Elmer, Foster City, CA, USA) on a PerkinElmer Cetus Thermocycler (PE Applied Biosystems) with 200 ng plasmid as template. Sequencing was carried out in both directions on an ABI 310 Automated Sequencer (PE Applied Biosystems) using the same primers as in the PCR reactions and following manufacturers protocol. Multiple clones of the selected samples were sequenced.

Sequence analysis. Sequences were aligned using the Mega alignment program in the DNAstar Sequence Analysis Software package (DNAStar Inc., Madison, WI, USA) on a Macintosh Quadra. Aligned sequences were analysed using maximum parsimony in PAUP 4.0, version beta2 (Swofford 1999), under the heuristic search option with random addition of taxa. Bootstrap resampling (1000 replicates) was also performed in PAUP.

\section{RESULTS}

\section{Restriction fragment length polymorphism}

RFLP analysis of the $650 \mathrm{bp}$ of the LSU rRNA gene revealed 1 major pattern across all 5 morphospecies. Both CfoI and TaqI (Fig. 2) digests gave uniform pat-
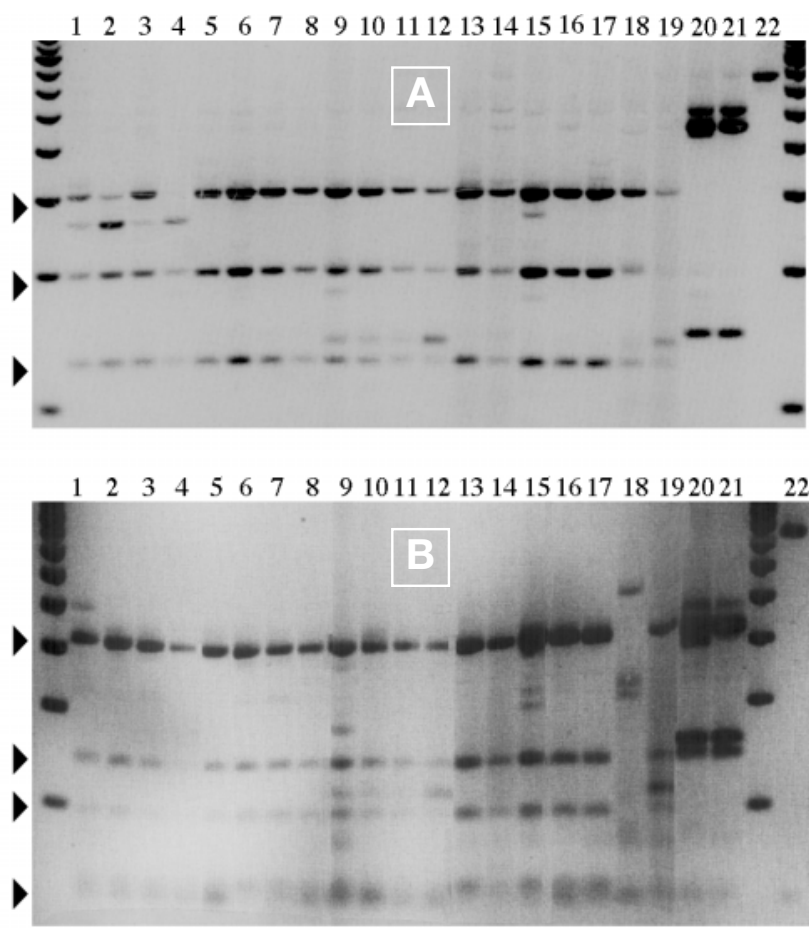

Fig. 2. Madracis, Montastraea annularis and Stephanocoenia michelinii. Restriction digests of the $650 \mathrm{bp}$ fragment of the Symbiodinium rDNA-LSU from 19 individuals. (A) CfoI; (B) TaqI. Bands marked with correspond with known LSUrDNA RFLPs (Baker et al. 1997). Numbers above lanes correspond to sample ID (Table 1)

tern for all species which corresponded to Symbiodinium Type B (bands marked with $\downarrow$, Baker et al. 1997). Some polymorphism is visible in both CfoI and TaqI digests but these still fall within Type B (see 'Discussion'). The RFLP patterns from Montastraea and Stephanocoenia (Fig. 2, Lanes 20 and 21) correspond to Symbiodinium Type C1 and C2 (Baker et al. 1997). Types A or B were not detected in $M$. annularis and S. michilinii RFLP digests.

\section{Sequencing and alignment}

As summarized in Table 1, 30 clones were sequenced from 12 individuals across the 5 morphospecies. Lengths of the sequences ranged from 646 to $648 \mathrm{bp}$, except Madracis formosa 25a (653 bp), which had a $6 \mathrm{bp}$ insert, and $M$. senaria 13c (640 bp), which had a $7 \mathrm{bp}$ deletion. All fragments were easy to align. Madracis zooxanthellae sequences were compared against known zooxanthellae types $\mathrm{A}, \mathrm{B}$ and $\mathrm{C}$ sequences drawn from the GenBank sequence database. Sequences of Madracis zooxanthellae were similar to a Type B zooxanthellae reference sequence obtained from Aiptasia pallida (GenBank U63484; Baker et al. 
1997). Zooxanthellae sequences from Montastraea and Stephanocoenia were identified as Type C as compared against Acropora cervicornis (GenBank U63481; Baker et al. 1997). The reference sequence for Symbiodinium Type A was from Pavona duerdeni (GenBank U63485). Individual sequences as well as the alignment have been submitted to GenBank (see Table 1 for accession numbers).

\section{Analyses of the sequence data}

Parsimony analysis of the Madracis zooxanthellae sequences resulted in 174 most parsimonious trees of which 1 is presented in Fig. 3. The $50 \%$ majority-rule consensus tree (Fig. 3, grey bar) shows that there is no significant phylogenetic structure among Type B zooxanthellae across hosts or depths. Reference sequences for Symbiodinium Types A, B and C (as discussed) and newly collected sequences from Montastraea and Stephanocoenia at Buoy 1 were included in the analysis. The resulting tree topology is congruent with the overall pattern in Baker \& Rowan (1997), including high bootstrap support.

\section{DISCUSSION}

\section{Zooxanthellae uniformity in Madracis species, habitats and locations}

Comparison of the Madracis zooxanthellae sequences with reference Symbiodinium sequences from GenBank shows that all Madracis morphospecies at the Buoy 1 site contain Type B zooxanthellae. There was no correlation of zooxanthellae variation with the different morphospecies from which they were obtained nor was there correlation of minor zooxanthellae polymorphisms with host depth (Fig. 3). In a recently completed phylogenetic study of Madracis using nuclear rDNAITS sequences, the 5 coral species have been found to be closely related, and at least 3 of the 5 may have hybridized in the recent past (Diekmann et al. 2001). The uniformity of the zooxanthellae type and distribution throughout the entire genus is consistent with vertical inheritance and/or host preference. We will return to these points later.

Nucleotide polymorphism within the Type B sequences (alignment available from GenBank) was compared with the CfoI and TaqI RFLP patterns (Fig. 2). The variation found involved mutations at $3 \mathrm{CfoI}$ restriction sites and 3 TaqI restriction sites in 12 and 4 cases respectively. The remaining 63 nucleotide differences were scattered across the alignment. A few nucleotide differences might be explained by PCR artifacts (mistakes by Taq-polymerase), but when many differences are observed across the length of a sequence, the more likely explanation is natural polymorphism caused by incomplete homogenization of the rDNA-LSU gene (Schlotterer \& Tautz 1994) within Type B cistrons. Since our analysis involves many zooxanthellae cells collected from 1 coral colony and not a single zooxanthellae, a slightly heterogeneous assemblage of zooxanthellae might also be contributing to the observed polymorphism.

While more intensive sampling in very shallow or very deep water might reveal the presence of Type A and Type $\mathrm{C}$ zooxanthellae within Madracis, we are rather doubtful. As discussed by Rowan (1998), Type A

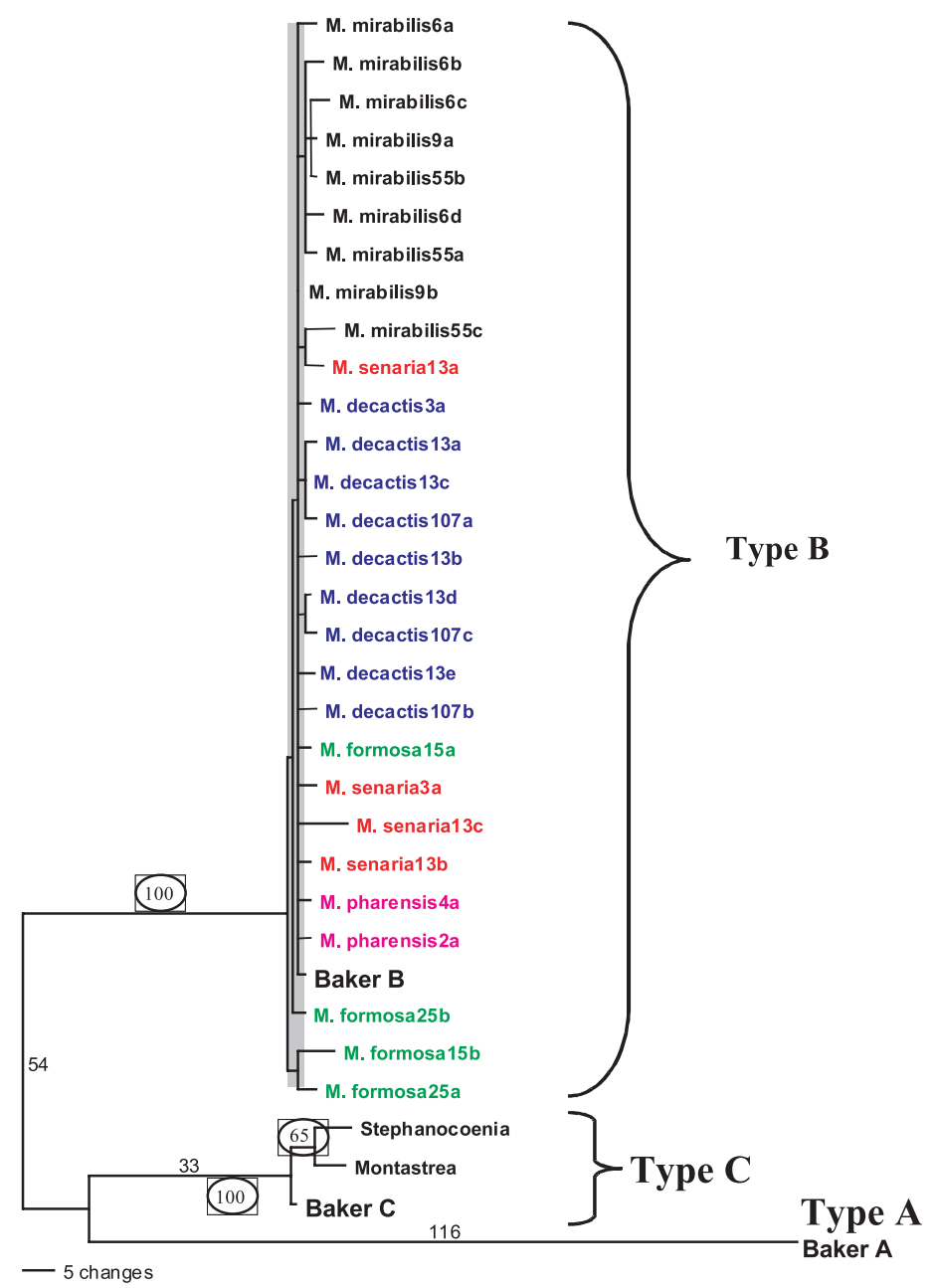

Fig. 3. One out of 174 most parsimonious trees based on rDNA-LSU sequence variation in Symbiodinium in different coral hosts. The grey line indicates the $50 \%$ majority-rule consensus line. Bootstrap values circled. Numbers above branches represent changes. Colors represent zooxanthellae sequences obtained from 1 coral species. Sample IDs correspond to coral individuals in Table 1. Baker A, B and C are reference sequences (Table 1) 
tends to be 'weedy' and would probably have been detected in our shallow samples $(<5 \mathrm{~m}, \mathrm{n}=7)$. Type $\mathrm{B}$ is known to be common across a range of depths (10 to $30 \mathrm{~m}, \mathrm{n}=12$ ) and Type $\mathrm{C}$ is mainly associated with lowlight environments ( $>30 \mathrm{~m}, \mathrm{n}=11$ ). Type $\mathrm{C}$ was found in our sampling of Montastraea (15.0 m, n = 1) and Stephanocoenia $(13.5 \mathrm{~m}, \mathrm{n}=1)$ at Buoy 1 . These results show that Types B and C are definitely present in the environment at the Buoy 1 study site and are, in principle, available to Madracis. Single individuals of Madracis species have been surveyed from 3 other sites in the Caribbean and all were found to have Symbiodinium Type B. These included $M$. mirabilis, $M$. decactis, M. senaria, M. formosa and $M$. pharensis (OED) from the neighbouring island of Bonaire $(80 \mathrm{~km}$ to the east); $M$. decactis from Caribbean Panama (Baker et al. 1997); and M. mirabilis from the US Virgin Islands (Rowan \& Powers 1991). These results suggest biogeographic, phylogenetic and temporal uniformity (at least over a $7 \mathrm{yr}$ period). However, without better sampling, this cannot be confirmed.

\section{One zooxanthellae type is probably the norm}

In the case of Madracis, it is clear that the absence of multiple zooxanthellae types and zonation with depth signals additional mechanisms whereby zooxanthellae and their coral hosts can adapt. As summarized in Table 2, a survey of Symbiodinium diversity from the recent literature shows that most corals probably have only 1 type. Keeping in mind that surveys of this type typically examine only 1 or a few individuals, it is still surprising that more diversity has not been detected. Models of physiological acclimatization (Falkowski et al. 1990, Brown 1997, Kinzie 1999) involving 1 symbiont type, as well as adaptation of the coral itself, need further exploration. On the one hand, Warner et al. (1999) found no correlation between algal phylotypes and their physiological tolerances. On the other hand, the differential production of a 'host factor', which elicits the release of newly fixed carbon by the zooxanthellae, may have different effects on different Symbiodinium types (Gates et al. 1999).

If Symbiodinium types are truly light-adapted (an hypothesis that has not been experimentally confirmed), then they would be expected to be differentially susceptible to bleaching (i.e. Type A and B < C) following Rowan et al. (1997). The ubiquity and wide distribution of Type B (Table 2) suggest that it may be the 'generalist' type in the Caribbean even though all 3 types are present. Alternatively, the uniformity of zooxanthellae in Madracis may be the result of different life history strategies and/or strain-sorting between Madracis and, e.g. Montastraea.

\section{The environmental pool}

The interactions between Symbiodinium and their coral hosts are active with high turnover. Seasonal variation in zooxanthellae density and chlorophyll concentration have been well documented (Dustan 1979, Gattuso et al. 1993). Stimson (1997) and Fagoonee et al. (1999) assigned this seasonal variation to host regulation of the zooxanthellae population. Recent longterm studies by Brown et al. (1999) and Fitt et al. (2000) have shown strong seasonal fluctuations of zooxanthellae populations coinciding with changes in physical environmental parameters. Zooxanthellae may also be part of the normal diet of corals (Boschma 1925, Steel \& Goreau 1977); consumption is thus an ongoing process (Titlyanov et al. 1998). Finally, zooxanthellae are expelled daily from their hosts back into the environment (Fagoonee et al. 1999, Baghdasarian \& Muscatine 2000). How long they are able to survive is unknown, but there is evidence that they are able to do so for short periods of time in amino-acid-rich microenvironments such as fish guts or other intermediate hosts (Gates et al. 1999). It has also been shown that there are free-living Symbiodinium (Carlos et al 1999). Viability and ubiquity of free-living and expelled forms are currently unknown. The compositional mix of types may also reflect a simple recycling of types by the resident corals, i.e. many corals with Type B will contribute B back to the pool; or background levels of Symbiodinium diversity may shift in response to environmental changes by themselves, i.e. temperature or light stress might select for another Symbiodinium type that could then become available for acquisition.

\section{Life-history strategies-are there host preferences?}

Corals acquire their zooxanthellae (Schwarz et al. 1999) by repeated environmental acquisition (i.e. open or horizontal symbiosis) but vertical inheritance (i.e. closed or vertical symbiosis) may also play more than an initial role in establishing host preferences (Trench 1987, reviewed in Rowan 1998). At present, it is not clear whether a particular coral host preferentially maintains a particular Symbiodinium type, and whether or not this is temporally or spatially variable-and if so, over what scales. Observations are mixed. Coffroth \& Santos (1997) found that juvenile gorgonian corals Plexaura kuna readily absorbed Symbiodinium Types A and $B$, but that adult populations tended to have only Type B. They suggested symbiont sorting during colony ontogeny. In contrast, experiments in anemones (Davy et al. 1997), where individuals were experimentally offered homologous or heterologous zooxanthellae, revealed that both types were readily phago- 
cytized and that over the 36 wk period of the study, both types were maintained.

Coral reproduction may also differentially affect long-term zooxanthellae acquisition. Broadcast spawners release positively buoyant egg and sperm bundles into the water column. The majority of broadcast spawning corals release gametes that lack zooxanthellae (Fadlallah 1983, Babcock \& Heyward 1986, Harrison \& Wallace 1990, Richmond \& Hunter 1990), and larvae must acquire their zooxanthellae by feeding (Trench 1987, Muller-Parker \& D'Elia 1997). In contrast, brooding corals release sperm into the water column, but they must reach eggs that are internally maintained. The negatively buoyant zygotes/larvae are brooded for days to several months (Harrison \& Wallace 1990) and, in most cases, already contain their initial batch of zooxanthellae upon release from the parent (e.g. Pocillopora damicornis [Richmond \& Hunter 1990], Goniastrea aspera [Sakai 1997]) and these come directly from the parent polyp (Benayahu \& Schleyer 1998). This suggests that broadcast spawning corals can only obtain their symbionts from the environment, whereas brooding corals may have a predisposition for the parental type (though not necessarily an obligatory one). Montastraea annularis is a broadcast spawner (Szmant-Froelich 1984), as is Acropora (Szmant 1986). Madracis is a brooder (M. J. A. Vermeij pers. comm.) and larvae are released which already contain zooxanthellae and apparently perpetuate the parental colony's zooxanthellae type. Our finding of only Type $\mathrm{B}$ zooxanthellae in 5 Madracis morphospecies over a broad depth range suggests a strong host preference (or host recognition) for Type B.

\section{Bleaching - an ecological opportunity?}

The correlation found among different types of Symbiodinium and host depth in the Montastraea annularis complex (Rowan \& Powers 1991, Rowan \& Knowlton 1995, Rowan et al. 1997) and in Acropora cervicornis (Baker et al. 1997) suggests that these corals are able to take advantage of different light regimes. This is especially important in terms of the phenomenon of 'coral bleaching' (Glynn 1991). Bleaching is the stress response of the coral polyp in which the zooxanthellae are partially to completely expelled from the host tissue. Stress factors include unusually high or low temperatures, high UV radiation and pollution (Brown \& Ogden 1993, Buddemeier \& Fautin 1993, Fang et al. 1998, Fagoonee et al. 1999). If the stress factor is severe and prolonged, the zooxanthellae may not be replaced, leading to the eventual death of the colony. Between these extremes, however, it has also been shown that even completely white coral tissue still contains a substantial number of zooxanthellae (Brown et al. 1999, Fitt et al. 2000). Coral bleaching has, therefore, been viewed as having mainly negative effects on the host. Another hypothesis, however, is that bleaching may function as an adaptive mechanism (Buddemeier \& Fautin 1993, Rowan \& Knowlton 1995, Ware et al. 1996, Rowan et al. 1997). Moderate stress and purging of zooxanthellae through the 'bleaching response', may lead to an 'instant' recalibration of the coral to the 'new' local, adaptive norm by reshuffling the endosymbiont assemblage.

The main problem at present is that we have 3 wellstudied cases (Montastraea, Acropora and Madracis) and a slew of surveys (Table 2 ) that present many alternative explanations. Even in the best studied case of the Montastraea annularis complex, where zooxanthellae diversity reigns, a generalization cannot be extended to other species in the genus. Billinghurst et al. (1997) investigated zooxanthellae diversity in $M$. cavernosa from Bermuda by means of RFLP of the SSU-rDNA and found only 1 RFLP pattern corresponding to Type C Symbiodinium in 62 individuals sampled over a 2 to $30 \mathrm{~m}$ depth range at 5 sites. The authors suggested that the uniformity of zooxanthellae in $M$. cavernosa in Bermuda might reflect reduced diversity of the zooxanthellae pool by biogeographic isolation, but clearly such an explanation does not apply to Madracis species sampled from Curaçao, Bonaire, Panama or the Virgin Islands, all of whom have only Type B.

Montastraea species, with their diverse assemblage of Symbiodinium, including plenty of Type B, have been most affected by bleaching, whereas Madracis species (as well as M. cavernosa), with only Type B, hardly ever bleach (Fitt \& Warner 1995, R. P. M. Bak pers. obs.). The fact that these different corals occur at similar depths, harbor at least some of the same zooxanthellae types, and yet respond differently to stress indicates that there is more to the bleaching response than the susceptibility of the zooxanthellae. The triggering mechanisms of the coral host that actually lead to exocytosis are only partially understood. Fang et al. (1998) found, e.g. that Acropora grandis synthesized heat shock proteins at lower temperatures than did the zooxanthellae and initiated expulsion even under minor temperature stress. Whether heat shock proteins are expressed differently in different coral hosts remains unknown. Normal seasonal changes in zooxanthellae density/host and (abnormal) environmental stress can also confound interpretations of the severity of bleaching episodes. Fagoonee et al. (1999) were able to show, in a multiple regression analysis of Acropora data, that seasonality was more important in explaining changes in zooxanthellae density than temperature or solar radiation perse. Therefore, subtle coral-specific differences in seasonal zooxanthellae density may also play a role. 


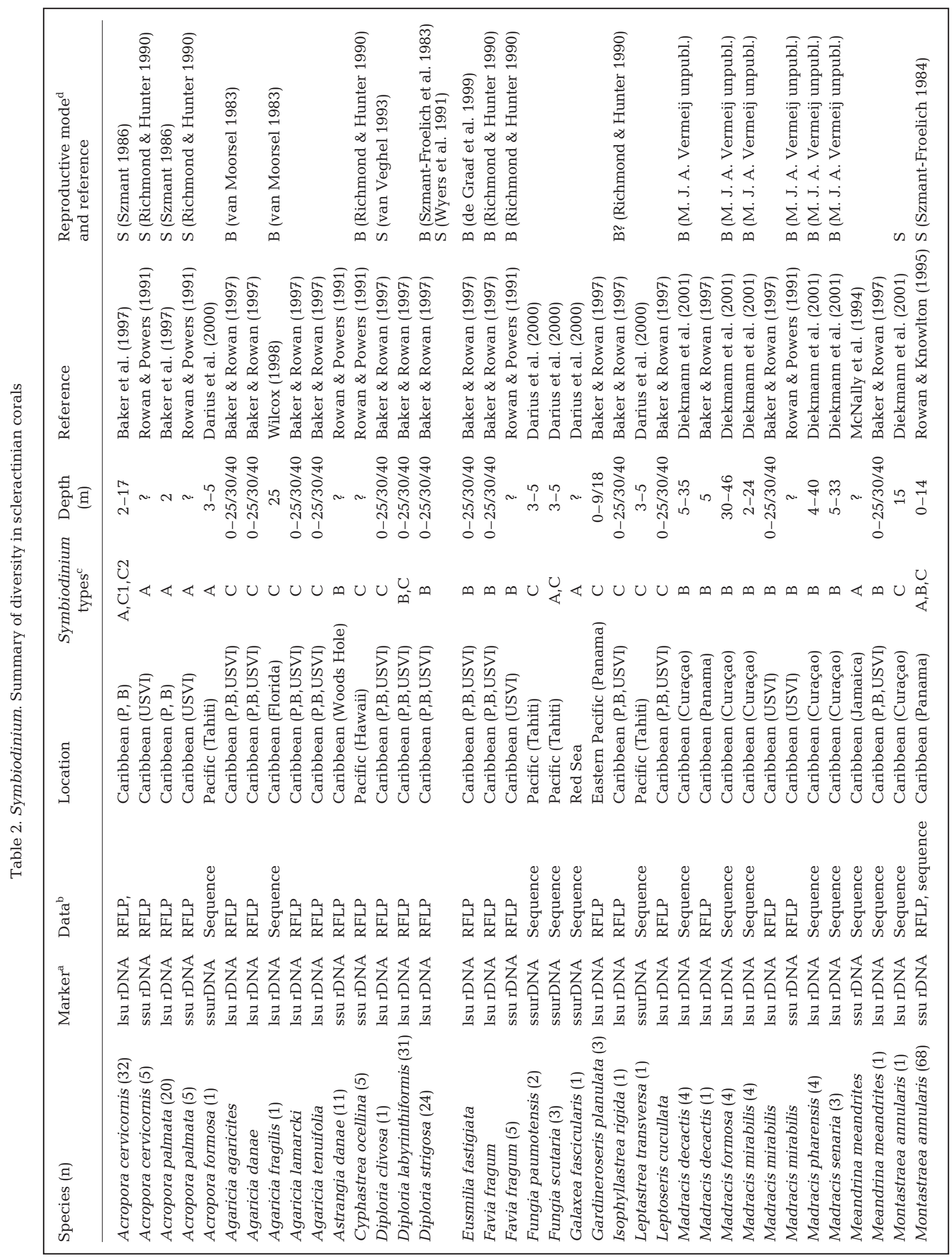

(Table continued on next page) 


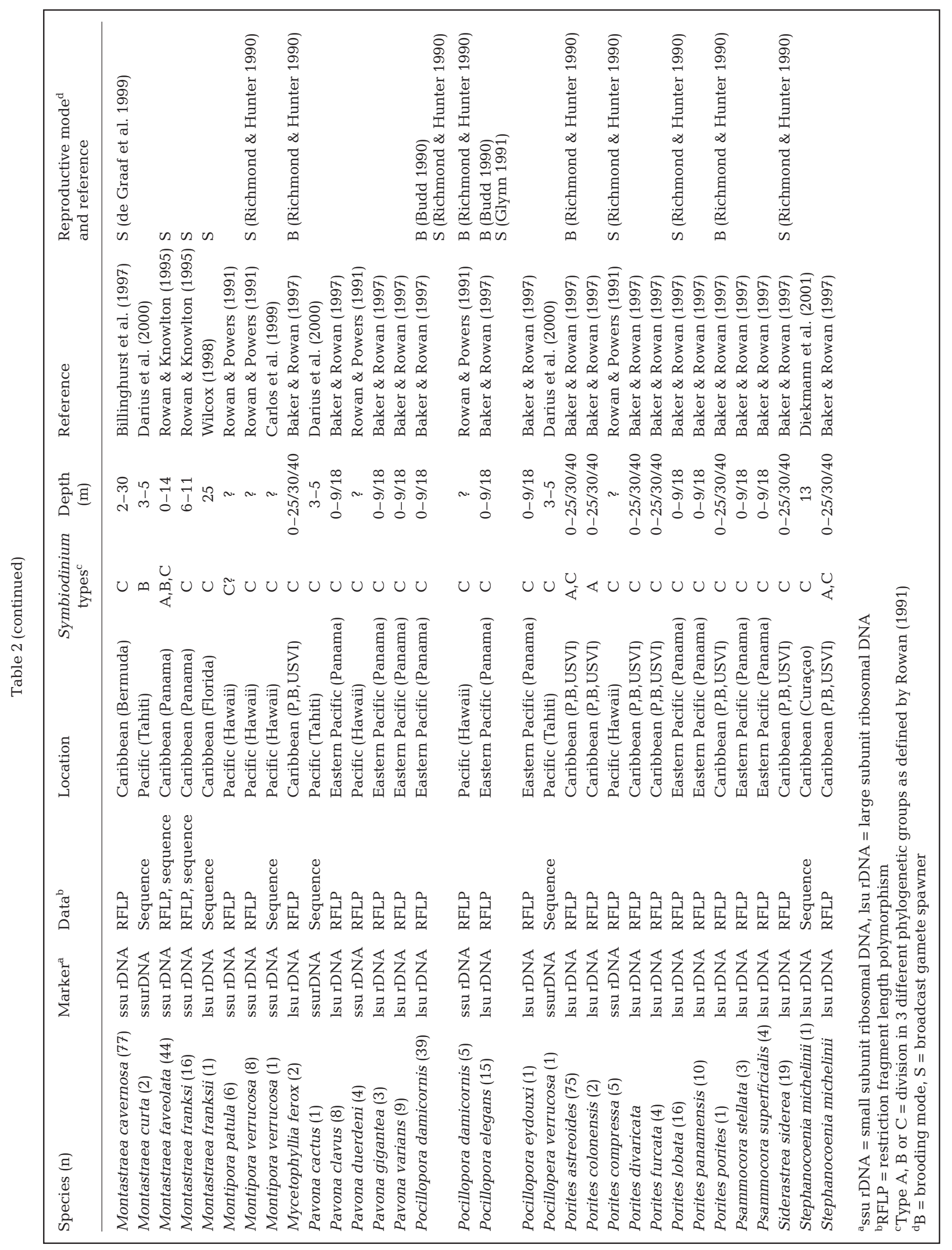




\section{CONCLUSIONS}

The complexity and flexibility of the coral-zooxanthellae symbiosis is only beginning to be understood. A challenge for future studies is to expand the scale of sampling and temporal observation of zooxanthellae in a select number of coral species using a more comparative approach. It is clear that coral-Symbiodinium symbioses are not evolutionarily constrained, speciesspecific associations. It is also clear that symbioses are not random. What remains unclear is the degree to which brooding and broadcasting strategies have long-term effects on associations, possibly involving some level of host recognition or preference; the degree to which the coral animal can influence physiological performance of the alga or vice versa; and the degree to which the environmental pool of zooxanthellae changes, e.g. as a seasonal response, as a routine expulsion by a particular host, by a bleaching event that affects particular hosts or Symbiodinium types more than others, or by micro-environmentally mediated conditions that promote the maintenance of freeliving symbionts. Although labor-intensive and technically challenging, such studies are needed in order to develop a better understanding of the relative importance of the factors that influence zooxanthellae diversity in a given host that may help to explain the longterm evolutionary survival of such a vulnerable group of organisms.

Acknowledgements. We thank the CARMABI foundation for providing research facilities. This study was supported by the Netherlands Foundation for the Advancements of Tropical Research (WOTRO project W84-405), which is funded by the Netherlands Organization for the Advancement of Research (NWO).

\section{LITERATURE CITED}

Babcock RC, Heyward AJ (1986) Larval development of certain gamete spawning scleractinian corals. Coral Reefs 5: 111-116

Baghdasarian G, Muscatine L (2000) Preferential expulsion of dividing algal cells as a mechanism for regulating algalcnidarian symbiosis. Biol Bull 199:278-286

Bak RPM (1977) Coral reefs and their zonation in the Netherlands Antilles. Am Assoc Pet Geol Stud Geol 4:3-16

Bak RPM, Engel MS (1979) Distribution, abundance and survival of juvenile hermatypic corals (Scleractinia) and the importance of life history strategies in the parent coralcommunity. Mar Biol 54:341-352

Bak RPM, Nieuwland G (1995) Long-term change in coral communities along depth gradients over leeward reefs in the Netherlands Antilles. Bull Mar Sci 56:609-619

Baker AC, Rowan R (1997) Diversity of symbiotic dinoflagellates (zooxanthellae) in scleractinian corals of the Caribbean and Eastern Pacific. Proc 8th Int Coral Reef Symp 2: 1301-1306

Baker AC, Rowan R, Knowlton N (1997) Symbiosis ecology of two Caribbean Acroporid corals. Proc 8th Int Coral Reef Symp 2:1295-1300

Benayahu Y, Schleyer MH (1998) Reproduction in Anthelia glauca (Octocorallia: Xeniidae): II. Transmission of algal symbionts during planular brooding. Mar Biol 131: 433-442

Billinghurst Z, Douglas AE, Trapido-Rosenthal HG (1997) On the genetic diversity of the symbiosis between the coral Montastrea cavernosa and zooxanthellae in Bermuda. Proc 8th Int Coral Reef Symp 2:1291-1294

Blank RJ, Trench RK (1985) Speciation and symbiotic dinoflagellates. Science 229:656-658

Blank RJ, Huss VAR, Kersten W (1988) Base composition of DNA from symbiotic dinoflagellates: a tool for phylogenetic classification. Arch Microbiol 149:515-521

Boschma H (1925) On the feeding reactions and digestion in the coral polyp Astrangia danae, with notes on its symbiosis with zooxanthellae. Biol Bull 49:407-439

Brown BE (1997) Coral bleaching: causes and consequences. Coral Reefs 16(Suppl): S129-S138

Brown BE, Ogden JC (1993) Coral bleaching. Sci Am 268: $44-50$

Brown BE, Dunne RP, Ambarsari I, Le Tissier MDA, Satapoomin U (1999) Seasonal fluctuations in environmental factors and variations in symbiotic algae and chlorophyll pigments in four Indo-Pacific coral species. Mar Ecol Prog Ser 191:53-69

Budd AF (1990) Longterm patterns of morphological variation within and among species of reef-corals and their relationship to sexual reproduction. Syst Bot 15:150-165

Buddemeier RW, Fautin DG (1993) Coral bleaching as an adaptive mechanism: a testable hypothesis. Bioscience 43: 320-326

Carlos AA, Baillie BK, Kawachi M, Maruyama T (1999) Phylogenetic position of Symbiodinium (Dinophyceae) isolates from Tridacnids (Bivalvia), Cardiids (Bivalvia), a sponge (Porifera), a soft coral (Anthozoa), and a free-living strain. J Phycol 35:1054-1062

Coffroth MA, Santos SR (1997) Early ontogeny of zooxanthellae-coral symbiosis - a preliminary report. Am Zool 37: 11A (Abstract)

Darius TH, Martin PM, Grimont PAD, Dauga C (2000) Small subunit rDNA sequence analysis of symbiotic dinoflagellates from seven scleractinian corals in a Tahitian lagoon. J Phycol 36:951-959

Davy SK, Lucas IAN, Turner RT (1997) Uptake and persistence of homologous and heterologous zooxanthellae in the temperate sea anemone Cereus pedunculatus (Pennant). Biol Bull 192:208-216

de Graaf M, Geertjes GJ, Videler JJ (1999) Observations on spawning of scleractinian corals and other invertebrates on the reefs of Bonaire (Netherlands Antilles, Caribbean). Bull Mar Sci 64(1):189-194

de Jong YDM, van der Wurff AWG, Stam WT, Olsen JL (1998) Studies on Dasyaceae. 3. Towards a phylogeny of the Dasyaceae (Ceramiales, Rhodophyta), based on comparative $r b c \mathrm{~L}$ gene sequences and morphology. Eur J Phycol 33:187-201

Diekmann OE, Bak RPM, Stam WT, Olsen JL (2001) Molecular genetic evidence for reticulate speciation in the coral genus Madracis from a Caribbean fringing reef slope. Mar Biol 139:221-233

Dustan P (1979) Distribution of zooxanthellae and photosynthetic chloroplast pigments of the reef-building coral Montastrea annularis Ellis and Solander in relation to depth on a West Indian coral reef. Bull Mar Sci 29:79-95 Fadlallah YH (1983) Sexual reproduction, development and 
larval biology in scleractiniancorals: a review. Coral Reefs 2:129-150

Fagoonee I, Wilson HB, Hassell MP, Turner JR (1999) The dynamics of zooxanthellae populations: a long-term study in the field. Science 238:843-845

Falkowski PG, Jokiel PL, Kinzie RA III (1990) Coral Reefs. In: Dubinsky ZE (ed) Ecosystems of the world, Vol 25. Elsevier, Amsterdam, p 89-107

Fang LS, Wang JT, Lin KL (1998) The subcellular mechanism of release of zooxanthellae during coral bleaching. Proc Natl Sci Counc Repub China Part B Basic Sci 22:150-158

Fitt WK, Warner ME (1995) Bleaching patterns of four species of Caribbean reef corals. Biol Bull 189:298-307

Fitt WK, McFarland FK, Warner ME, Chilcoat GC (2000) Seasonal patterns of tissue biomass and densities of symbiotic dinoflagellates in reef corals and relation to coral bleaching. Limnol Oceanogr 45:677-685

Freudenthal HD (1962) Symbiodinium gen. Nov. and Symbiodinium microadriaticum sp. Nov., a zooxanthella: taxonomy, life cycle, and morphology. J Protozool 9:45-52

Gates RD, Bil KY, Muscatine L (1999) The influence of an anthozoan 'host factor' on the physiology of a symbiotic dinoflagellate. J Exp Mar Biol Ecol 232:241-259

Gattuso JP, Yellowlees D, Lesser M (1993) Depth- and lightdependent variation of carbon partitioning and utilization in the zooxanthellate scleractinian coral Stylophora pistillata. Mar Ecol Prog Ser 92:267-276

Glynn PW (1991) Coral reef bleaching in the 1980's and possible connections with global warming. Trends Ecol Evol (TREE) 6:175-179

Harrison PL, Wallace CC (1990) Reproduction, dispersal and recruitement of scleractinian corals. In: Dubinsky Z (ed) Ecosystems of the world: coral reefs, Vol 2. Elsevier, New York, p 133-207

Hillis DM, Dixon MT (1991) Ribosomal DNA: molecular evolution and phylogenetic inference. Q Rev Biol 66:411-453

Kinzie RA III (1999) Sex, symbiosis and coral reef communities. Am Zool 39(1):80-91

Kinzie RA III, Chee GS (1979) The effect of different zooxanthellae on the growth of experimentally reinfected hosts. Biol Bull 156:315-327

Langer MR, Lipps JH (1994) Phylogenetic incongruence between dinoflagellate endosymbionts (Symbiodinium) and their host foraminifera (Sorites): small-subunit ribosomal RNA gene sequence evidence. Mar Micropaleontol 26: 179-186

Lenaers G, Maroteau L, Michot B, Herzog M (1998) Dinoflagellates in evolution: a molecular phylogenetic analysis of large subunit ribosomal RNA. J Mol Evol 29:40-51

McNally KL, Govind NS, Thome PE, Trench RK (1994) Smallribosomal DNA sequence analysis and the inferred phylogeny among symbiotic dinoflagellates (Pyrrophyta). J Phycol 30:316-329

Meesters EH, Hilterman M, Kardinaal E, Keetman M, De Vries M, Bak RPM (2001) Colony size-frequency distributions of scleractinian coral populations: spatial and interspecific variation. Mar Ecol Prog Ser 209:43-54

Muller-Parker G, D'Elia CF (1997) Interactions between corals and their symbiotic algae. In: Birkeland C (ed) Life and death of coral reefs. Chapman and Hall, New York, p 96-113

Ohno T, Katoh T, Yamasu T (1995) The origin of algal-bivalve photo-symbiosis. Palaeontology (Leeds) 38:1-21

Richmond HR, Hunter CL (1990) Reproduction and recruitment of corals: comparisons among the Caribbean, the tropical Pacific, and the Red Sea. Review. Mar Ecol Prog Ser 60:185-203
Rowan R (1991) Molecular systematics of symbiotic algae. J Phycol 27:661-666

Rowan R (1998) Diversity and ecology of zooxanthellae on coral reefs. J Phycol 34:407-417

Rowan R, Knowlton N (1995) Intraspecific diversity and the ecological zonation in coral-algal symbiosis. Proc Natl Acad Sci USA 92:2850-2853

Rowan R, Powers DA (1991) A molecular genetic classification of zooxanthellae and the evolution of animal-algal symbiosis. Science 251:1348-1351

Rowan R, Powers DA (1992) Ribosomal RNA sequences and the diversity of symbiotic dinoflagellates (zooxanthellae). Proc Natl Acad Sci USA 89:3639-3643

Rowan R, Knowlton N, Baker A, Jara J (1997) Landscape ecology of algal symbionts creates variation in episodes of coral bleaching. Nature 388:265-269

Sakai K (1997) Gametogenesis, spawning, and planula brooding by the reef coral Goniastrea aspera (Scleractinia) in Okinawa, Japan. Mar Ecol Prog Ser 151:67-72

Schlotterer C, Tautz D (1994) Chromosomal homogeneity of Drosophila ribosomal DNA arrays suggests intrachromosomal exchanges drive concerted evolution. Curr Biol 4: $777-783$

Schoenberg DA, Trench RK (1976) Specificity of symbiosis between marine cnidarians and zooxanthellae. In: Macke GO (ed) Coelenterate ecology and behavior. Plenum, New York, p 423-432

Schwarz JA, Krupp DA, Weis VM (1999) Late larval development and onset of symbiosis in the scleractinian coral Fungia scutaria. Biol Bull 196:70-79

Steele RD, Goreau NI (1977) The breakdown of symbiotic zooxanthellae in the seanamone Phyllactis (=Oulactis) flosculifera (Actinaria). J Zool (Lond) 181:421-437

Stimson J (1997) The annual cycle of density of zooxanthellae in the tissues of field and laboratory-held Pocillopora damicornis (Linnaeus). J Exp Mar Biol Ecol 214:35-48

Swofford DL (1999) PAUP*. Phylogenetic analysis using parsimony ( ${ }^{*}$ and other methods). Version 4. Sinauer Associates, Sunderland, MA

Szmant AM (1986) Reproductive ecology of Caribbean reef corals. Coral Reefs 5:43-54

Szmant-Froelich AM (1984) Reef coral reproduction: diversity and community patterns. In: Advances in reef science. University of Miami, p 122-123

Szmant-Froelich AM, Reutter M, Riggs L (1983) Sexual reproduction in Caribbean reef corals. Am Zool 23:961

Titlyanov EA, Titlyanova TV, Loya Y, Yamazato K (1998) Degradation and proliferation of zooxanthellae in planulae of the hermatypic coral Stylophora pistillata. Mar Biol 130: 471-477

Trench RK (1987) Dinoflagellates in non-parasitic symbiosis. In: Taylor FJR (ed) The biology of dinoflagellates, Botanical Monographs. Blackwell Scientific Publications, Oxford, p 530-570

Trench RK (1992) Microalgal-invertebrate symbioses. Encycl Microbiol 3:129-142

van Moorsel GWNM (1983) Reproductive strategies in two closely related stony corals (Agaricia, Scleractinia). Mar Ecol Prog Ser 13:273-283

van Oppen MJH, Diekmann OE, Wiencke C, Stam WT, Olsen JL (1994) Tracking dispersal routes: phylogeography of the Arctic-Antarctic disjunct seaweed Acrosiphonia arcta. J Phycol 30:67-80

van Veghel MLJ (1993) Multiple species spawning on Curaçao reefs. Bull Mar Sci 52:1017-1021

van Veghel MLJ, Bak RPM (1993) Intraspecific variation of a dominant Caribbean reef building coral, Montastrea annu- 
laris: genetic, behavioural and morphometric aspects. Mar Ecol Prog Ser 92:255-265

Ware JR, Fautin DG, Buddemeier RW (1996) Patterns of coral bleaching: modeling the adaptive bleaching hypothesis. Ecol Model 84:199-214

Warner ME, Fitt WK, Schmidt GW (1999) Damage to photosystem II in symbiotic dinoflagellates: a determinant of coral bleaching. Proc Natl Acad Sci USA 96:8007-8012

Editorial responsibility: Otto Kinne (Editor), Oldendorf/Luhe, Germany
Wells JW (1973) New and old scleractinian corals from Jamaica. Bull Mar Sci 23:16-55

Wilcox TP (1998) Large-subunit ribosomal RNA systematics of symbiotic dinoflagellates: morphology does not recapitulate phylogeny. Mol Phylogen Evol 10:436-448

Wyers SC, Barnes HS, Smith SR (1991) Spawning of hermatypic corals in Bermuda: a pilot study. Hydrobiologia 216/217:109-116

Submitted: March 23, 2001, Accepted: July 12, 2001

Proofs received from author(s): January 25, 2002 